Keywords:

Environmental performance

Life cycle inventory

Wood based panel

Sustainability

Production system technology

Historic:

Recebido 17/10/2012

Aceito 06/1 I/2013

Palavras chave:

Desempenho ambiental

Inventário do ciclo de vida

Painel de madeira reconstituída

Sustentabilidade

Tecnologia de sistema de produção

Correspondence: piekarski@uttpr.edu.br
Cassiano Moro Piekarski', Antonio Carlos de Francisco², Leila Mendes da Luz², Tiago Henrique de Paula Alvarenga ${ }^{3}$, Juliana Vitoria Messias Bittencourt ${ }^{2}$

\section{ENVIRONMENTAL PROFILE ANALYSIS OF MDF PANELS PRODUCTION: STUDY IN A BRAZILIAN TECHNOLOGICAL CONDITION}

ABSTRACT: The main goal of this study was to analyze the environmental profile of MDF panel manufacturing in the Brazilian industry in terms of energy, emissions and dependence on renewable sources. The study was conducted by using the methodology of Life Cycle Assessment (LCA), specifically through the development of the first Life Cycle Inventory $(\mathrm{LCl})$ of MDF in a Brazilian industry. The life cycle inventory and the production processes analysis were constructed using Umberto ${ }^{\circledR}$ v.5.6 software and following the ISO 14040 series. The study covers the life cycle of MDF production from gate-to-gate perspective, involving the on-site manufacturing system. The functional unit was defined in $1 \mathrm{~m}^{3}$ of MDF. About $76 \%$ of energy required to produce MDF is thermal (52.8\% of thermal energy is required for the drying process of wood fiber). $\mathrm{CO}_{2}$ is a major emission during the MDF production, where natural gas contributes to $96.7 \%$ of total $\mathrm{CO}_{2}$ fossils. It was observed a low dependence of non-renewable source (19.2\%) compared with the literature.

\section{ANÁLISE DO PERFIL AMBIENTAL DA PRODUÇÃO DE PAINÉIS MDF: ESTUDO EM UMA CONDIÇÃO TECNOLÓGICA BRASILEIRA}

RESUMO: O principal objetivo, neste artigo, é analisar o perfil ambiental da produção do painel de madeira MDF produzido em uma indústria brasileira em termos de energia, emissões e dependência de fontes renováveis. $O$ estudo foi baseado na metodologia de Avaliação do Ciclo de Vida (ACV), especificamente por meio do desenvolvimento do primeiro Inventário do Ciclo de Vida (ICV) do MDF de uma indústria brasileira. O Inventário do Ciclo de Vida e a análise dos processos produtivos foram construídos utilizando o software Umberto ${ }^{\circledR} \mathrm{v} .5 .6$, atendendo aos requisitos normativos da série de normas ISO 14040. O estudo abrangeu o ciclo de vida da produção do MDF na perspectiva gate-togate, envolvendo os limites in-loco da planta fabril. A unidade funcional adotada foi I $\mathrm{m}^{3} \mathrm{de}$ MDF. Cerca de $76 \%$ da energia requerida para a produção do MDF é de origem térmica (onde $52,8 \%$ é demandada pelo processo de secagem da fibra de madeira). $\mathrm{O} \mathrm{CO}_{2}$ é a maior emissão observada durante a produção do MDF, na qual o gás natural contribui com $96,7 \%$ do total de $\mathrm{CO}_{2}$ de origem fóssil. Foi observada uma baixa dependência de fontes não renováveis (19,2\%) quando comparada à literatura. 


\section{INTRODUCTION}

Impacts associated with forest-based products and their production systems are being researched by various science field. In the context of modern industry, Life Cycle Assessment (LCA) is an important method to environmental management (LÖFGREN et al., 20I I) and evaluates environmental performance of the product, process or pathway along its partial or whole life cycle. Hence, LCA is a useful tool to analyse the environmental profile of Medium Density Fiberboard (MDF) production.

From the 1990s on, efforts were done in order to analyze the environmental performance of forestry products through LCA methodology application (RIVELA et al., 2007). On the other hand, wood panels began to be studied only in the late 2000s. Studies (BENETTO et al., 2009; GONZÁLEZ-GARCÍA et al., 2009; RIVELA et al., 2006) about the environmental impact of wood panels, particularly the medium-density fiberboard (MDF) were developed in the USA (WILSON, 20I0), Canada (ATHENA SUSTAINABLE MATERIALS INSTITUTE, 2009) and Europe (RIVELA et al., 2007; WASTE \& RESOURCES ACTION PROGRAMME - WRAP, 2009) in order to provide the environmental information about the panel, evaluate their impacts, propose improvements in the production system, direct scientific studies focusing on reducing environmental impacts and, finally, to promote innovation. Notwithstanding the diverse benefits of LCA, there have been some difficulties to disseminate this methodology in Brazil mainly by the lack of Life Cycle Inventories (LCI) (RIBEIRO; SILVA, 20I0).

The aim of this paper was to analyze the environmental profile of MDF manufacturing in a Brazilian industry in terms of energy, emissions and dependence on renewable sources. To analyze the environmental aspects, this paper presents the first reported $\mathrm{LCl}$ of Brazilian MDF, based on its technological conditions.

\section{MATERIALS AND METHODS}

The study was developed in compliance with the ISO series 14040 (ASSOCIAÇÃO BRASILEIRA DE NORMAS TÉCNICAS - ABNT, 2009a, 2009b) and current state of the art LCA practices (UNITED NATIONS ENVIRONMENTAL PROGRAMME - UNEP, 20II). The software Umberto ${ }^{\circledR}$ v.5.6 Acad. was used for calculations.

\section{Goal and scope definition}

This study aims to develop high-quality data (Life Cycle Inventory - LCl) on the environmental profile of MDF in the Brazilian industry in order to analyze its environmental profile. A Brazilian MDF industry with an approximate process production of $300,000 \mathrm{~m}^{3}$ per year and considered representative of the 'state of the art' was selected to study the process in detail. The industry of this study belongs to one of the largest business group manufacturer of reconstituted wood panels in Latin America, this fact justifies the selection of the company. The study covers the life cycle of MDF manufacturing (gate-to-gate plant system), documenting all inputs and outputs.

\section{Functional unit}

The functional unit provides a reference to which all inputs and outputs are referred (ABNT, 2009a). The volumetric unit is adopted as reference to recorded on-site production data and was used as a functional unit in previous wood panel studies (ATHENA..., 2009; RIVELA et al., 2007; WILSON, 20I0; WRAP, 2009). Therefore, all flows, materials, and emissions were expressed as a function of the functional unit: $1.0 \mathrm{~m}^{3}$ of finished MDF, oven-dried and without decorative coatings. For those LCA practitioners who conduct studies based on mass, $1.0 \mathrm{~m}^{3}$ of MDF studied weights $683.2 \mathrm{~kg}$ (on oven-dried mass).

\section{Description of production process and system boundary}

Medium Density Fiberboard (MDF) is an engineered wood product formed by breaking down softwood into wood fibers, often in a defibrator, combining it with wax and resin, and forming panels by applying high temperature and pressure. It is a building material similar in application to plywood but it is made up of separated fibers, not wood veneers. MDF has a typical density of $600-800 \mathrm{~kg} \cdot \mathrm{m}^{-3}$ and similar manufacturing processes are used in all MDF industries around the world.

The MDF manufacturing process is highly automated, process-controlled, and fairly linear. Figure I illustrates the on-site process of the industry studied. The process consists of the following steps identified in Table I.

\section{Data collection, data quality analysis and calculations procedures}

The collection of high quality primary data is fundamental to make a reliable analysis. All data were 


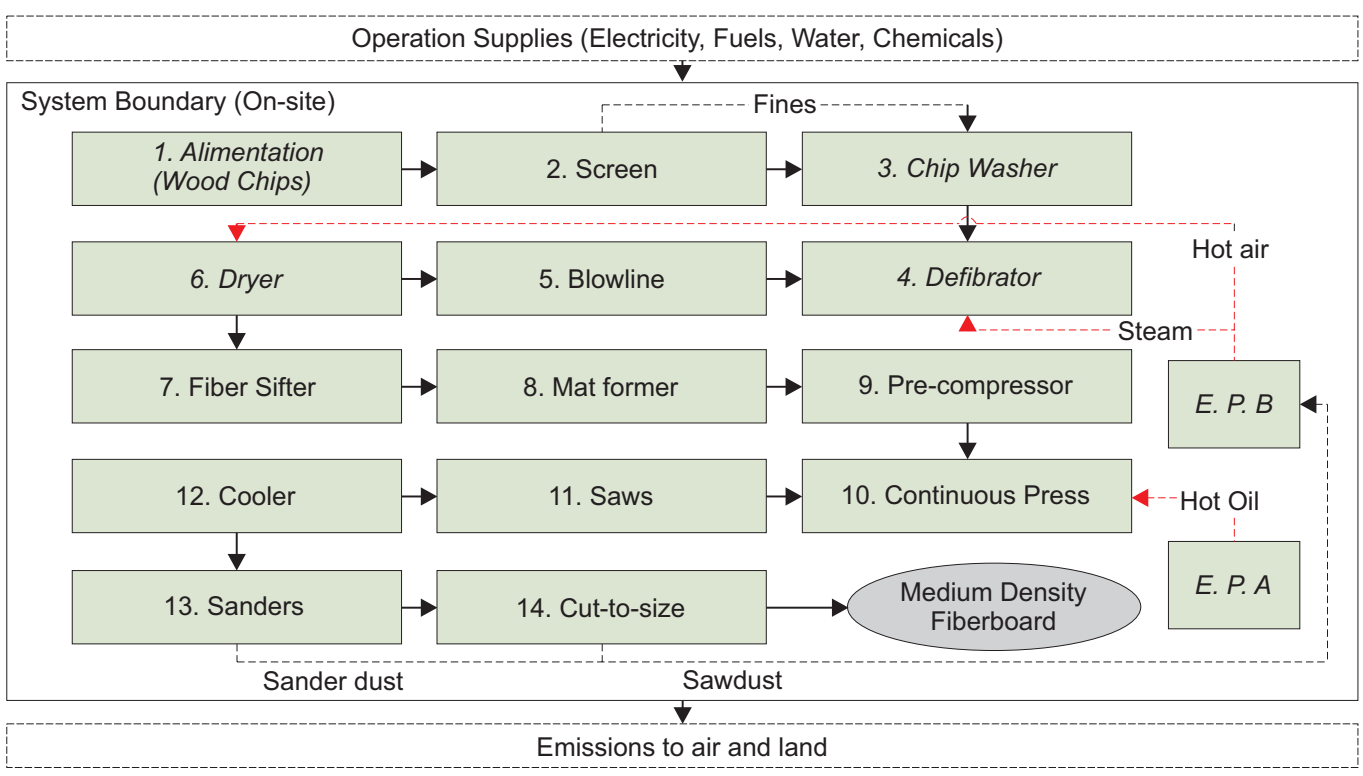

FIGURE I Flow Sheet of MDF Manufacturing System.

FIGURA I Diagrama de Fluxos do Sistema de Produção do MDF.

TABLE I Description of MDF production process.

TABELA I Descrição dos processos produtivos do MDF.

Description of production process

The wood chips are delivered to the mill by truck. The chips are made of pine and eucalyptus ( $88 \%$ and $12 \%$,
respectively), and are stored in the wood yard, without being covered. A Chip Reclaimer pull the wood chips to process,
where the same shall be replaced by a measurement thread (Metering Screw) to homogenize the amount of material
that goes to the chip screen through belt conveyor. The moisture content of the chips can range from 40 to $70 \%$ on an
oven-dried weight basis. Annually, are consumed approximately 220,000 tons of wood chips. Small Particles (Fines) and Large Particles/Peel (Oversized) are removed from the chips during the screening. The Fines

$\Phi$ returns to the processor and the oversized are sold as biomass to another mill. Approximately $6 \%$ of the total chips

n. that pass through the screen are destined as fines whereas $0.5 \%$ as oversizes. Only the appropriate sized chips are fed to Chip Wash.

The chips are washed to remove dirt. The residues and extracted materials are treated as effluent through a centrifuge

$\therefore \frac{\bar{v}}{\bar{\sigma}}$ on the mill. During washing, the first part is the Scrap separator where a rotating wheel with paddles ensures that all chips will be submerged and the scrap is separated and discharged into a conveyor drainer. The chips goes to a tank where it will be pumped to Screw drainer.

After washing, the fines return to process mixing with the chips in conveyor mixer. A level control device measures the amount of material is fed in steaming bin and sends signal to metering bin to request more or less chips or fines.

ᄒ After steaming bin, the transfer screw takes the material until plug screw which removes the extractives and water excess from the chips. The chips are softened in a steam-pressurized digester (pressure between I-9 bar) and then transported into a pressurized refiner chamber. The heated wood chips are then refined, a process of mechanically reducing it into fibers by shearing the wood between two rotating metal disks that separate the fibers; this process is accomplished by the use of a pressurized disk refiner. The average consumption of steam is $0.5 \mathrm{~kg}$ of steam per $\mathrm{kg}$ of fiber produced.

In this process, resin and other additives are blended with the fibers. Friction and contact between fibers may help to

3 distribute the resin. The resin used is based on Urea-Formaldehyde (UF) and are consumed $65.6 \mathrm{~kg} \cdot \mathrm{m}^{-3}$ of MDF. In this

을 process is also added wax in wood fibers $\left(3.4 \mathrm{~kg} \cdot \mathrm{m}^{-3}\right.$ of MDF produced), urea $\left(0.8 \mathrm{~kg} \cdot \mathrm{m}^{-3}\right.$ of MDF produced) and urea scavenger (that allows to control the emission of free formaldehyde of resin, $4.7 \mathrm{~kg} \cdot \mathrm{m}^{-3}$ of MDF produced).

$\bar{\varpi}$ The fibers drying occur in tube dryer of hot air, where the hot air is responsible for drying the fiber. The hot air stream

evaporates the moisture and conducts the fiber. The hot air dryer is generated by the power plant, usually by combustion of wood dust generated by the mill or eventually by natural gas.

To be continued...

Continua... 
TABLE I Continued...

TABELA I Continuação...

Description of production process

\begin{tabular}{|c|c|}
\hline 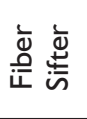 & $\begin{array}{l}\text { After drying, the fibers ( } 7-9 \% \text { moisture content) pass through a wind filter (Sifter). The sifter is used to remove clumps } \\
\text { of fibers or other heavy materials that may cause problems to the process and the final product. The dry fiber is selected } \\
\text { and delivered to the mat former. }\end{array}$ \\
\hline 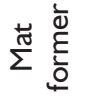 & $\begin{array}{l}\text { The dry and selected fiber goes to a feeder bin with a uniform distribution through the action of pendulum fiber } \\
\text { distribution. The fibers are uniformly distributed by former and become a mat fiber. }\end{array}$ \\
\hline 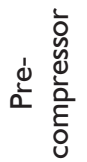 & $\begin{array}{l}\text { The mat fiber cross the deaerator (to remove air between the fibers) and, finally, the mat is pre-compressed by the } \\
\text { compressor. The mat is moistened with its upper and lower surface during the formation process to be pressed. The } \\
\text { water used to humidify the mat is represented in } 2.5 \mathrm{~L} \cdot \mathrm{m}^{-3} \text { of MDF produced. }\end{array}$ \\
\hline
\end{tabular}

The continuous press operates as a function of temperature and pressure. Press operates at about $170-230^{\circ} \mathrm{C}$ and 5.2 $\mathrm{MPa}$ in a sufficient time to cure the resin and at a pressure to consolidate the mat to a desired density, thereby controlling the physical properties of the panel. The continuous press is heated by hot oil generated in the thermal plant. As a consequence of temperature rise is the emission of particulates and the release of free formaldehyde $\left(\mathrm{H}_{2} \mathrm{CO}\right)$. The continuous press produces annually about $300,000 \mathrm{~m}^{3}$ of MDF panel with thickness from $5.5 \mathrm{~mm}$ to $30 \mathrm{~mm}$.

The diagonal saw cuts the panel in the transverse direction The panels produced by the continuous press are cut into three parts for commercialization.

$\frac{\bar{\varpi}}{0}$ The MDF goes first to a cooler, where it stays for $40 \mathrm{~min}$. After that, the produced panels remain resting for $48 \mathrm{~h}$ so that

o their physical and mechanical properties are stabilized.

ป $\quad$ Panels are sanded on both major surfaces to acquire the proper thickness and smoothness. Sander dust coming off this

process is recycled back into the manufacturing process to be used as fuel for the thermal plant. Approximately $7.4 \%$

$\approx$ O of the material is removed by the action of sandpaper. About $74.8 \%$ of dust generation comes from the sanders action.

do The large panels are sawn to dimensions of panel width and length. Panel trim is hammer milled into particles and sent 吉 $\frac{N}{\omega}$ back into the processor. All the sawdust is sent back to the processor in the thermal plant. Approximately $7.4 \%$ of the $J^{3}$ material is removed by the sandpapers action. About $74.8 \%$ of dust generation comes from the action of sanders.

It consists of two Thermal Plants. The first (E.P. A) is responsible for heating the hot oil used in the continuous press

क्. where its fuel is natural gas. The E.P. A produces around 0.187 MWh of hot oil per $\mathrm{m}^{3}$ of MDF produced. The second (E.P.

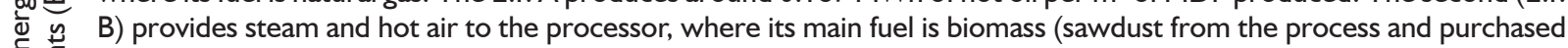
from other plants) and occasionally it also use natural gas as fuel. The E.P. B generates about $15 \mathrm{Gcal}^{-h^{-1}}$ to hot air in dryer process and I0Gcal $\cdot h^{-1}$ in steam to defibrator process.

related to inputs and outputs of the MDF manufacturing in a Brazilian mill during a one year period (2010). The data was collected through questionnaires. The questionnaires were developed based on two models: i) Questionnaire developed by the Athena... (2009) for the Life Cycle Assessment (LCA) of the Canadian MDF, which follows the methodology proposed by the ISO I 4040 series and; ii) Sheets of collection data suggested by the ISO I 4044 (ABNT, 2009b).

Data was collected from managers responsible for each specific area and the treatment of this data was performed by analysis of the $\mathrm{LCl}$. The assessment of the quality of $\mathrm{LCl}$ had been carried out using the methodology provided in Umberto ${ }^{\circledR}$ v. 5.6 Acad., which is adapted from UNEP (2007). The Umberto $®$ software was used to model, calculate, and visualize material and energy flow systems.
The procedures for calculating the $\mathrm{LCl}$ involved the mass and energy balances of the process defined at the boundary on-site. Inputs and outputs of materials and energy for each elementary process were quantified. It was defined for the units "kg" and "MJ" for mass and energy balances, respectively. All data was computed in dry mass. A mass balance considering all inputs materials and all outputs of products and emissions had a difference of $0.41 \%$ that is suitable within the maximum $5 \%$ balance required in the literature (RIVELA et al., 2006; WILSON, 2010).

Emission inventory data about MDF processes was developed using primary and secondary sources. The primary data was collected directly from the industry. For diesel used in chips transportations, the emissions data (secondary source) was inventoried from bibliographic data (BAUER, 2007; SCWAIGER; ZIMMER, 200I) (Table 2). 
TABLE 2 Secondary data sources used.

TABELA 2 Fontes de dados secundárias utilizadas.

\begin{tabular}{|c|c|c|c|c|}
\hline Activity Area & $\begin{array}{c}\text { Compound } \\
\text { emitted }\end{array}$ & $\begin{array}{c}\text { Emission } \\
\text { factors }\end{array}$ & Unit & Reference \\
\hline \multicolumn{5}{|l|}{ Alimentantion } \\
\hline \multirow{8}{*}{$\begin{array}{l}\text { Transportation } \\
\text { of chips } \\
\text { (Diesel used') }\end{array}$} & $\mathrm{CO}_{2}$ & 9.04 & $\begin{array}{l}g \cdot M J^{-1} \\
\text { fuel }\end{array}$ & Bauer (2007) \\
\hline & $\mathrm{CO}$ & 0.0435 & $\begin{array}{l}g \cdot \mathrm{MJ}^{-1} \\
\text { fuel }\end{array}$ & Bauer (2007) \\
\hline & $\mathrm{N}_{2} \mathrm{O}$ & 0.02 & $\begin{array}{c}g \cdot \mathrm{MJ}^{-1} \\
\text { fuel }\end{array}$ & $\begin{array}{l}\text { Schwaiger and } \\
\text { Zimmer (200I) }\end{array}$ \\
\hline & $\mathrm{CH}_{4}$ & 0.013 & $\begin{array}{l}g \cdot \mathrm{MJ}^{-1} \\
\text { fuel }\end{array}$ & Bauer (2007) \\
\hline & $\mathrm{NO}_{x}$ & 0.108 & $\begin{array}{l}g \cdot \mathrm{MJ}^{-1} \\
\text { fuel }\end{array}$ & Bauer (2007) \\
\hline & NMVOC & 0.0378 & $\begin{array}{l}g \cdot \mathrm{MJ}^{-1} \\
\text { fuel }\end{array}$ & Bauer (2007) \\
\hline & $\mathrm{SO}_{2}$ & 0.0139 & $\begin{array}{l}g \cdot \mathrm{MJ}^{-1} \\
\text { fuel }\end{array}$ & Bauer (2007) \\
\hline & $\mathrm{Pb}$ & 3.00 E-06 & $\begin{array}{l}g \cdot \mathrm{MJ}^{-1} \\
\text { fuel }\end{array}$ & Bauer (2007) \\
\hline
\end{tabular}

'Specific characteristics of diesel: Density $=0.85 \mathrm{Kg} \cdot \mathrm{L}$, Higher heating value $(\mathrm{HHV})=36.23 \mathrm{MJ} \cdot \mathrm{Kg}$.

In MDF manufacturing process, the energy balances are done mainly to determine the expected energy consumption to remove the desired amount of water from the wood fibers during processing (WILSON, 2010). The average Moisture Content (MC) of wood material coming into the mill in this study was $54.12 \%$ on an oven-dry weight basis. The targeted $M C$ for the dried material with resin applied was $6-10 \%$, in mat formation. The MC of the finished MDF was approximately $7.3 \%$ on an oven-dry. The average thickness of the panels produced was $16 \mathrm{~mm}$ and the average density was 683.2 $\mathrm{kg} \cdot \mathrm{m}^{-3}$ on an oven-dried weight basis.

\section{RESULTS AND DISCUSSION}

The data related in this paper form the scientific analyse of environmental profile of MDF manufactured in the Brazilian industry. The company's production capacity is approximately $300,000 \mathrm{~m}^{3}$ of MDF per year and its production system is the same and it is in consonance to researched and reported by Banco Nacional de Desenvolvimento Econômico e Social - BNDES (2010) in the study of Brazilian wood panels industries. Therefore, in general this study is representative for the MDF Brazilian industry.

Furthermore, the MDF production process reported in this paper is also similar to the world technology state-of-art for the MDF manufacturing described by Rivela et al. (2007).

In this context, the life cycle inventory ( $\mathrm{LCl}$ ) was done and analysed in terms of emissions, energy and dependence on renewable sources. The $\mathrm{LCl}$ can be used as evidence to the environmental impacts of MDF (future LCA studies) and to be a part of the decisionmaking process towards environmental issues such as sustainability, green building, green purchasing, carbon storage, climate change, eco-innovation and eco-design.

\section{Life cycle inventory}

All inputs and outputs for the on-site manufacture of MDF were obtained from the industry and the inventory data of the MDF manufacturing system that are shown in Table 3. The inputs produced $1.0 \mathrm{~m}^{3}$

TABLE 3 On-site inputs and outputs for $1.0 \mathrm{~m}^{3}$ of MDF. TABELA 3 Entradas e Saídas para I,0 m³ de MDF.

\begin{tabular}{|c|c|c|}
\hline Production data & Unit & Unit $\cdot \mathrm{m}^{-3}$ \\
\hline \multicolumn{3}{|l|}{ Inputs } \\
\hline \multicolumn{3}{|l|}{ Wood $^{a}$} \\
\hline Chips (Eucalyptus) & $\mathrm{kg}$ & 80.7 \\
\hline Chips (Pinus) & $\mathrm{kg}$ & 617 \\
\hline \multicolumn{3}{|l|}{ Chemicals $^{\mathrm{b}}$} \\
\hline Wax & $\mathrm{kg}$ & 3.4 \\
\hline Urea-formaldehyde resin & $\mathrm{kg}$ & 65.6 \\
\hline Urea scavenger & $\mathrm{kg}$ & 4.7 \\
\hline Ammonium Sulfate & $\mathrm{kg}$ & 0.1 \\
\hline Urea & $\mathrm{kg}$ & 0.8 \\
\hline \multicolumn{3}{|l|}{ Electricity } \\
\hline Electricity & MJ & 1009.7 \\
\hline \multicolumn{3}{|l|}{ Fuels } \\
\hline Natural Gas & $\mathrm{m}^{3}$ & 17.4 \\
\hline Diesel & $\mathrm{L}$ & 0.4 \\
\hline Sawdust (purchased) & $\mathrm{kg}$ & 87.4 \\
\hline Sawdust (in-mill generated) & $\mathrm{kg}$ & 80.22 \\
\hline \multicolumn{3}{|l|}{ Water Use } \\
\hline Water (on-site treated) & L & 110.4 \\
\hline Artesian Water & $\mathrm{L}$ & 22.1 \\
\hline \multicolumn{3}{|l|}{ Outputs $^{a}$} \\
\hline Medium Density Fiberboard (MDF) & $\mathrm{kg}$ & 683.2 \\
\hline Bark mulch (sold) & $\mathrm{kg}$ & 3.5 \\
\hline Wood waste (sold) & $\mathrm{kg}$ & 4.3 \\
\hline
\end{tabular}

a Wood and Bark weights given as oven dry.

${ }^{b}$ Chemicals weights at $100 \%$ solids. 
of MDF (683.2 kg) and consisted of $697.7 \mathrm{~kg}$ of wood chips on an oven-dry weight basis, resin, scavenger, wax, and ammonium sulfate. Electricity, water, and fuels are also necessary in on-site system boundary to produce the MDF. The emissions are listed separately (Table 4).

TABLE 4 On-site outputs for $1.0 \mathrm{~m}^{3}$ of MDF. TABELA 4 Saídas para $1,0 \mathrm{~m}^{3}$ de MDF.

\begin{tabular}{lccc}
\hline Emissions data & Unit & $U^{\prime}$ nit $\cdot \mathrm{m}^{-3}$ & $\%$ \\
\hline Outputs & & & \\
\hline $\begin{array}{l}\text { Medium Density Fiberboard } \\
\text { (MDF) }\end{array}$ & $\mathrm{kg}$ & 683.2 & \\
\hline Emissions to air & & & \\
\hline Carbon Dioxide, $\mathrm{CO}_{2}$ (fossil) & $\mathrm{kg}$ & 34.7 & $76.9 \%$ \\
Carbon Monoxide, $\mathrm{CO}$ & $\mathrm{kg}$ & 4.5 & $10.0 \%$ \\
Nitrogen Dioxide, $\mathrm{N}_{2} \mathrm{O}$ & $\mathrm{kg}$ & 2.17 & $4.8 \%$ \\
Methane, $\mathrm{CH}_{4}$ & $\mathrm{~kg}$ & $1.6 \mathrm{E}-3$ & $4 \mathrm{E}-3 \%$ \\
Nitrogen oxides, $\mathrm{NO}_{x}$ & $\mathrm{~kg}$ & 1.27 & $2.8 \%$ \\
Total VOCs & $\mathrm{kg}$ & 1.12 & $2.5 \%$ \\
Particulate & $\mathrm{kg}$ & 0.6 & $1.3 \%$ \\
Sulfur Dioxide, $\mathrm{SO}_{2}$ & $\mathrm{~kg}$ & 0.04 & $0.1 \%$ \\
Lead, $\mathrm{Pb}$ & $\mathrm{kg}$ & $3.9 \mathrm{E}-7$ & $\mathrm{IE}-6 \%$ \\
Formaldehyde, $\mathrm{H}_{2} \mathrm{CO}$ & $\mathrm{kg}$ & 0.5 & $1.1 \%$ \\
Sulfuric Acid, $\mathrm{H}_{2} \mathrm{SO}_{4}$ & $\mathrm{~kg}$ & 0.12 & $0.3 \%$ \\
Sulfur Oxides, $\mathrm{SO}_{x}$ & $\mathrm{~kg}$ & 0.12 & $0.3 \%$ \\
\hline Emissions to land & & & \\
\hline Boiler Fly Ash & $\mathrm{kg}$ & 1.9 & $42.2 \%$ \\
Wood waste & $\mathrm{kg}$ & 2.6 & $57.8 \%$ \\
\hline W & &
\end{tabular}

a Wood and Bark weights given as oven dry

${ }^{b}$ Chemicals weights at $100 \%$ solids

The main MDF raw material is wood, in a ratio of $88 \%$ of total wood for pine chips and $12 \%$ of eucalyptus chips. In Brazil, the wood for the MDF manufacturing is provided exclusively from dedicated forests. Nevertheless, there are recent studies that have been analyzed the addition of waste to produce wood panels in Brazil (BARROS FILHO et al., 20I I; SILVA et al., 20I2). According to Silva et al. (20I3), unlike that in Brazil, in the USA and Europe the wood used to produce wood panels is mostly waste wood (preconsumer, e.g., from forest operations and sawmills, and postconsumer).

It can be noted that urea-formaldehyde resin (UFR) is the chemical most used to produce MDF. The UFR bind the wood fibers together and guarantees good physical-mechanical properties of the panel. The scavenger is used as an additive to capture excess of formaldehyde emissions during the press process of MDF panel.
The water system of the MDF industry is a closed loop system. Therefore, emissions to water are not included in this study. For $1.0 \mathrm{~m}^{3}$ of MDF, were used I I 0.4 L of water by Water Treatment Plant (WTP) and 22.I L from artesian water. Bark mulch and wood wastes generated in the MDF process were delivered to be sold as a biomass for others industries. Additionally, there were generated boiler fly ash $\left(1.9 \mathrm{~kg} \cdot \mathrm{m}^{-3}\right)$ and wood wastes $\left(2.06 \mathrm{~kg} \cdot \mathrm{m}^{-3}\right)$ that were sent to be used as composting for agriculture.

Values reported in table 4 summarized average values of emissions from the on-site MDF Brazilian industry. Similarly to the literature (WILSON, 20 I0), the air emissions of Brazilian MDF process are generated due to three reasons. The first is caused by mechanical processing of wood that can result in particulate wood emissions of various sizes. The second is caused when wood and resin are exposed to elevated temperatures during the pressing and drying process. The last reason refers to the combustion of fuels as wood, diesel, and natural gas.

For this particular industry, the total energy demand required for the production of $1.0 \mathrm{~m}^{3} \mathrm{MDF}$ is $4320 \mathrm{MJ}$. Table 5 presents the inventory of energy for the production of $1.0 \mathrm{~m}^{3}$ of MDF studied.

The energy for the MDF production results from sources of electricity, wood, natural gas, and hot oil, while diesel fuel is responsible for powering transport in the plant. The interpretation and analysis of energy aspects are laid out in sequence.

\section{Energy analysis}

Electrical power is used all over the manufacturing process in order to operate equipment inside the plant, such as conveyors, grinders, fan motors, hydraulic motors, and sanders, among others. The thermal energy is generated by two energy plants. The Energy Plant A (E.P. A) is responsible for the heating of the hot oil used in the continuous press where its fuel is natural gas. The second, Energy Plant B (E.P. B) provides steam and hot air to the process, where its main fuel is biomass (Sawdust from the processor and purchased from other plants) and occasionally it also burns natural gas as fuel. Figure 2 illustrates the total electric power demand compared to the consumption of thermal energy at the specific elementary processes.

Approximately $76 \%\left(3301.2 \mathrm{MJ} \cdot \mathrm{m}^{-3}\right)$ of the demand for energy is thermal, where $40 \%\left(\right.$ I738.8 MJ. $\mathrm{m}^{-3}$ ) comes from thermal energy required for drying fibers 
TABLE 5 Energy Inventory to produce $1.0 \mathrm{~m}^{3}$ of MDF.

TABELA 5 Inventário de Energia para produção de $1,0 \mathrm{~m}^{3}$ de MDF.

\begin{tabular}{|c|c|c|c|c|c|c|c|}
\hline Energy data & Unit & Unit $\cdot \mathrm{m}^{-3}$ & $M J \cdot m^{-3}$ & $\%$ Relative & Energy data & Unit & Unit $\cdot \mathrm{m}^{-3}$ \\
\hline Inputs & & & & & Outputs & & \\
\hline Electric Energy & KWh & 0.28 & 1008 & $23.3 \%$ & MDF & $\mathrm{kg}$ & 683.2 \\
\hline Natural Gas & $\mathrm{m}^{3}$ & 17.40 & 684 & $15.8 \%$ & Boiler Fly Ash & $\mathrm{kg}$ & 1.9 \\
\hline Diesel Oil & L & 0.41 & 10.8 & $0.3 \%$ & Wood Waste & kg & 2.6 \\
\hline Wood Dust (Purchased) & $\mathrm{kg}$ & 87.39 & 1368 & $31.7 \%$ & & & \\
\hline Sawdust (Generated in mill) & $\mathrm{kg}$ & 80.22 & 1260 & $29.2 \%$ & & & \\
\hline Sanding Dust & $\mathrm{kg}$ & 50.27 & 936 & $21.7 \%$ & & & \\
\hline Sawdust & $\mathrm{kg}$ & 29.95 & 324 & $7.5 \%$ & & & \\
\hline Total & - & - & 4330.8 & $100 \%$ & & & \\
\hline
\end{tabular}

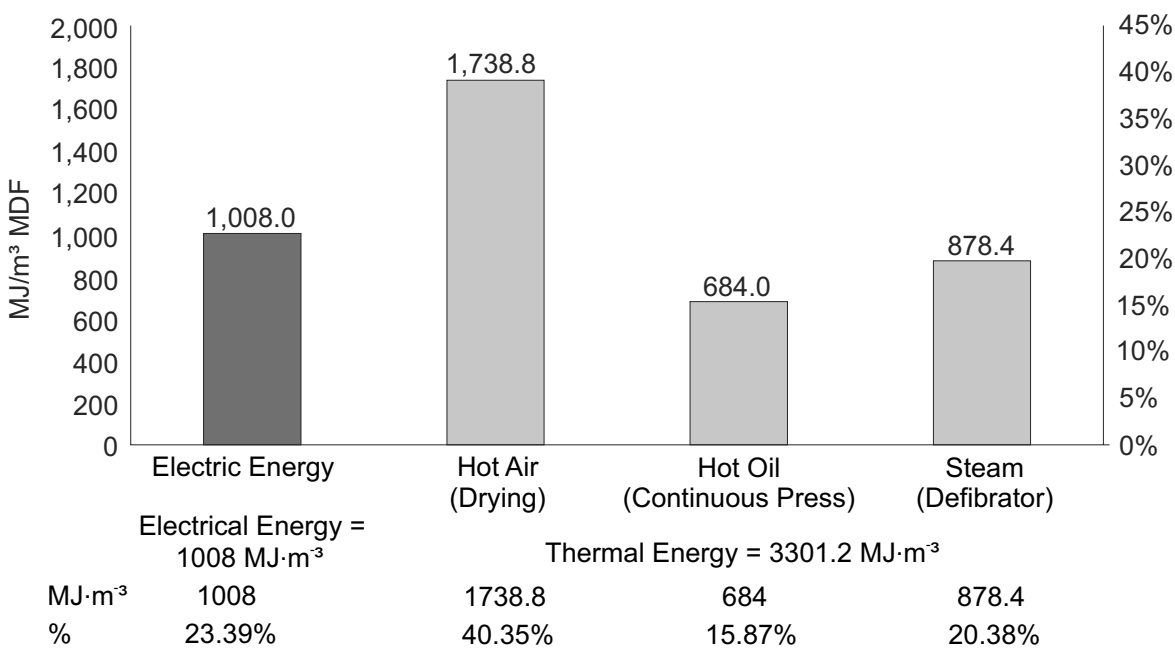

FIGURE 2 Energy Demand in MDF production: Electrical versus Thermal Energy.

FIGURA 2 Demanda de Energia na Produção do MDF: Energia Elétrica versus Térmica.

(hot air dryer). The demand for electricity represents $24 \%\left(1008 \mathrm{MJ} \cdot \mathrm{m}^{-3}\right)$ of the total energy demand. The energy plant responsible for the generation of steam and hot air (E.P. B) is operated with the combustion of natural gas and wood fuel (sawdust). Figure 3 represents the contribution of each energy source used in each energy plant (E.P. A and E.P. B) to generate a $1.0 \mathrm{~m}^{3}$ of MDF in the period studied.

The sawdust purchased (External Biomass) and the sawdust generated (Recycle Biomass) accounts for $91.7 \%$ of the total heat generated by E.P. B. The burning of natural gas represents $8.3 \%$ of the total thermal energy generated in this energy plant.

This means that less than $10 \%$ of the fuel sources used to generate steam and hot air are fossil fuels and non-renewable natural resources. Nevertheless, the thermal plant that heats the hot oil (E.P. A) is exclusively dependent on burning natural gas.

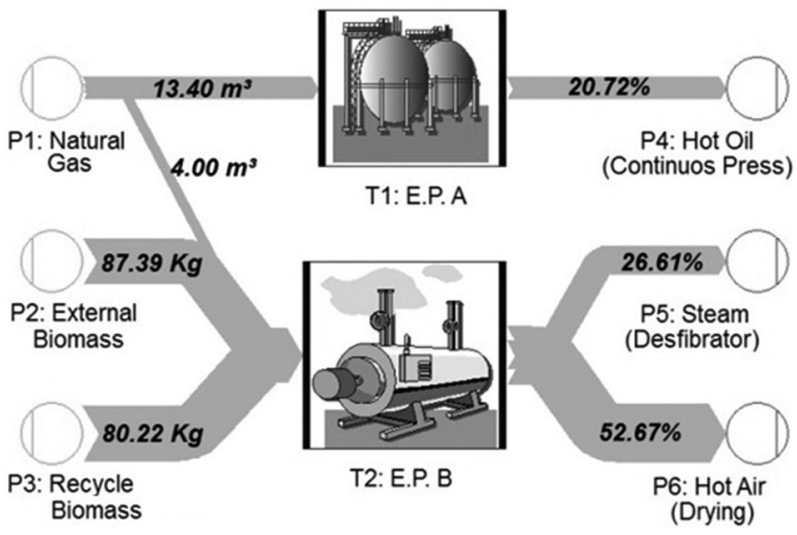

FIGURE 3 Thermal Energy balance for $1.0 \mathrm{~m}^{3}$ of MDF.

FIGURA 3 Balanço de Energia Térmica para $1,0 \mathrm{~m}^{3}$ do MDF.

The interest in reducing fossil fuels in order to reduce global warming, coupled with the increase in fuel prices and electricity, makes the energy issue a focal 
point of importance in the coming years to mills that seek to maintain the competitiveness reducing their costs and their dependence on fossil fuels (WILSON, 20I0).

\section{Emissions analysis}

On-site outputs for MDF production involve a small quantity of emission to the land (wood waste and boiler fly ash to agricultural use), and air emissions (see Table 4).

Carbon Dioxide involves the highest emission contribution in MDF production. In detail, the $\mathrm{CO}_{2}$ (fossil) comprises $76.9 \%$ of total emissions $\left(34.7 \mathrm{~kg} \cdot \mathrm{m}^{-3}\right)$. In this study, it was tracked the $\mathrm{CO}_{2}$ for fossil-fuel sources. The $\mathrm{CO}_{2}$ from combustion of biogenic sources is not considered a greenhouse gas (GHG) for the reason that its carbon life cycle is a closed loop in that the $\mathrm{CO}_{2}$ (biogenic) is reabsorbed by the growing of trees, liberating oxygen to the atmosphere and consuming the carbon to make more wood (UNITED STATES ENVIRONMENTAL PROTECTION AGENCY - USEPA, 2003; WILSON, 20 I0). Therefore, the $\mathrm{CO}_{2}$ emissions from combustion of wood fuels were not reported in the survey.

The $\mathrm{CO}_{2}$ is emitted from three elementary processes (Figure 4). The processes are: i) Alimentations - $\mathrm{CO}_{2}$ derived from the combustion of diesel fuel; ii) Drying (E.P. B) - $\mathrm{CO}_{2}$ derived from the combustion of natural gas in the Energy Plant B (E.P. B). The $\mathrm{CO}_{2}$ generated is conducted by hot air used in the dryer; iii) Thermal plant $-\mathrm{CO}_{2}$ derived from the combustion of natural gas used in E.P. A for heating the hot oil.

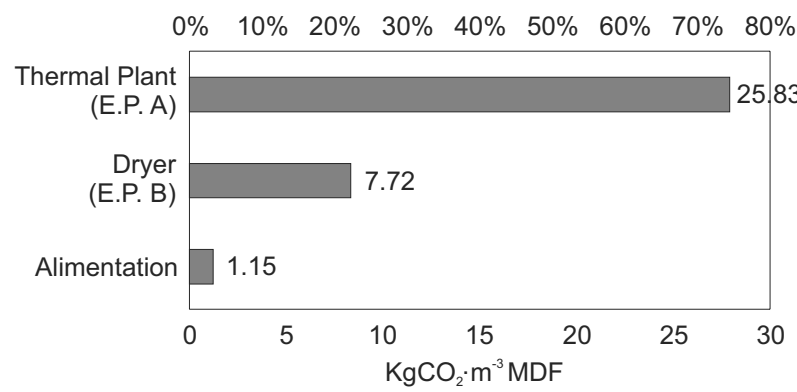

FIGURE $4 \mathrm{CO}_{2}$ fossil contribution per elementary processes. FIGURA 4 Contribuição do $\mathrm{CO}_{2}$ fóssil por processos elementares.

The combustion of natural gas in E.P. A has the largest impacts on the fossil $\mathrm{CO}_{2}$ emissions (with a contribution of $74.5 \%$ ). The use of natural gas in E.P. B characterizes $22.2 \%$ and the burning of diesel in alimentation represents $3.3 \%$ of $\mathrm{CO}_{2}$ emissions.

About other compounds, the carbon monoxide (CO) is the second largest contributor (10\%) to emissions, generated in the E.P. B. NOx (2.8\%) and VOCs $(2.5 \%)$ are generated in the following processes: alimentation, drying and thermal plant. $\mathrm{CH}_{4}, \mathrm{~N}_{2} \mathrm{O}$, and $\mathrm{Pb}$ are generated in reason of the combustion of diesel oil.

The particulate emission that occur in the deliberator, drying, pressing, sawing and sanding process, represents $1.3 \%\left(0.6 \mathrm{~kg} \cdot \mathrm{m}^{-3}\right)$ of total air emissions. The formaldehyde $\left(\mathrm{H}_{2} \mathrm{CO}\right)$ emissions are related to the use of UFR. Moreover, the type and amount of resin used, the scavenger use, the pressing time, and the thickness of the panel, guarantees the physical-mechanical properties of MDF and at the same time, its influence on the quantity of formaldehyde $\left(\mathrm{H}_{2} \mathrm{CO}\right)$ emitted. The other emissions $\left(\mathrm{SO}_{2}, \mathrm{H}_{2} \mathrm{SO}_{4}\right.$, and $\left.\mathrm{SO}_{\mathrm{X}}\right)$ totaled $0.9 \%$ of air emissions on the on-site MDF industry.

\section{Renewable sources dependence}

The $\mathrm{LCl}$ analysis of the MDF allows verifying the contribution of non-renewable and fossil fuels in the manufacturing system. Figure 5 provides an overview of all the energy sources used to produce $1.0 \mathrm{~m}^{3}$ of MDF in this study.

The contribution of renewable sources in MDF production represents $80.8 \%$ of total sources of energy required to produce $1 \mathrm{~m}^{3}$ of MDF. The study reported a low dependence of fossil and non-renewable sources (19.2\%) when compared with other studies (ATHENA..., 2009; RIVELA et al., 2007; WILSON, 20I0). Furthermore, the natural gas used in E.P. A represents $63 \%$ of the total non-renewable and fossil sources.

Regarding the use of electricity, Brazilian electric mix was taken into account. Brazilian electricity is considered a clean system based on its unique characteristics, mainly the prevalence of hydropower (RIBEIRO; SILVA, 20I0). The use of renewables in Brazilian electricity production is approximately $86.3 \%$ (BRASIL, 20I I, base year 20I0). In this way, electricity contributes $16 \%$ of total non-fossil sources and $25 \%$ of total renewable sources for MDF manufacturing.

Compared with the literature, the study of Silva et al. (2013) shows that for the production of 1.0 $\mathrm{m}^{3}$ wood panel MDP (Medium Density Particleboard) in Brazil are consumed $507 \mathrm{MJ}$ electricity. The significant difference is due mainly to the electricity consumption in defibrator process during the MDF production.

Wood fuel is considered global-warming and climate-change neutral (WILSON, 2010). The use of wood as fuel has benefits; it is a sustainable and renewable fuel that is taking the place of fossil fuel. In 


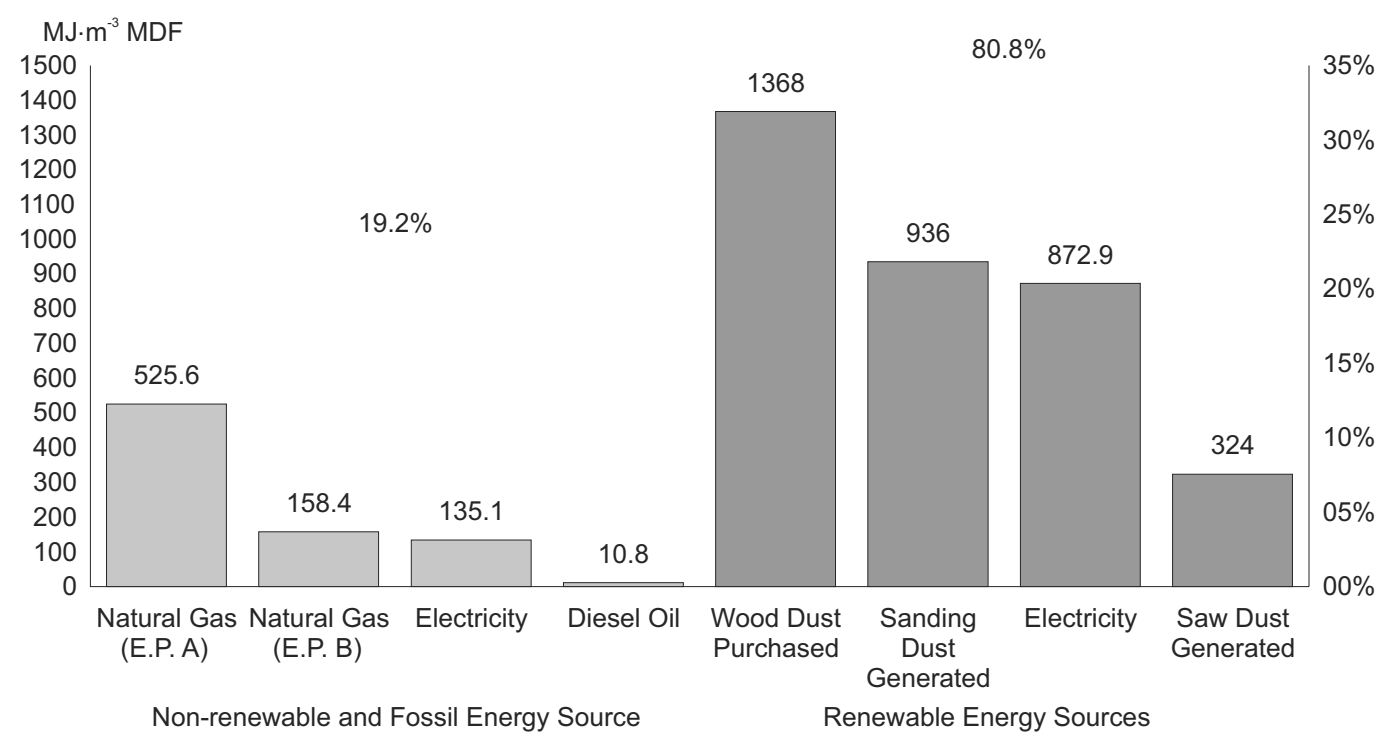

FIGURE 5 Consumption of renewable and non-renewable source in MDF production.

FIGURA 5 Consumos de fontes renováveis não renováveis na produção do MDF.

terms of energy, the industry produces $41.4 \%$ of its total consumption. The energy comes from wood fuel generated in the process (renewable energy source). The MDF industry purchased approximately $45.3 \%$ of its demand, while $54.7 \%$ were generated in the boundaries of the system being studied.

Furthermore, we recommend increasing the part of renewable energy used in thermal plants, upon availability, more wood fuels. These modifications would allow reducing the use of non-renewable and fossils sources and decreasing emission levels for $\mathrm{CO}_{2}$ fossils, for example.

\section{CONCLUSIONS}

This study presented a $\mathrm{LCl}$ for the production of $1.0 \mathrm{~m}^{3}$ of MDF manufacturing in the Brazilian industry (on-site system boundary). Special attention was paid to the inventory analysis in terms of energy, emissions, and renewable sources dependence. Although this study reports the technological state-of-art of MDF production system in Brazil, it is noteworthy that due to specific conditions of this case (specific consumptions, Brazilian electricity matrix, modal systems and raw materials) the results are restricted to industry-specific conditions of this study.

In order to produce $1.0 \mathrm{~m}^{3}$ of MDF was required $4320 \mathrm{MJ}(76.6 \%$ thermal and $23.4 \%$ electric energy, for the specific conditions of the industry surveyed). Recycled wood fuel in the industry represents $41.4 \%$ of its total energy consumption. $52.8 \%$ of thermal energy is required for the drying process of wood fiber. About emissions, $\mathrm{CO}_{2}$ is a major emission during the MDF production system. Natural Gas contributes with $96.7 \%$ of total $\mathrm{CO}_{2}$ fossil. $\mathrm{CO}_{2}$ emission from the energy plant B (E.P. B) can be saved using more wood fuels instead of natural gas.

The results can be used for strategic decisions for improving the environmental performance of MDF. For example, changing the E.P. B for a thermal plant that uses wood residues as fuel can decrease the level of dependence of non-renewable sources (from approximately $19.2 \%$ to $7.1 \%$ ) and reduce the $\mathrm{CO}_{2}$ fossil emissions.

\section{ACKNOWLEDGMENTS}

The Authors would like to thank the financial support under Fundação Araucária, CAPES/CNPq and the collaboration of the industry surveyed.

\section{REFERENCES}

ASSOCIAÇÃO BRASILEIRA DE NORMAS TÉCNICAS. NBR ISO 14040: gestão ambiental: avaliação do ciclo de vida: princípios e estrutura. Rio de Janeiro, 2009a. 21 p.

ASSOCIAÇÃO BRASILEIRA DE NORMAS TÉCNICAS. NBR ISO 14044: gestão ambiental: avaliação do ciclo de vida: requisitos e orientações. Rio de Janeiro, 2009b. 46 p.

ATHENA SUSTAINABLE MATERIALS INSTITUTE. A cradleto-gate LCA of Canadian Medium Density Fiberboard (MDF). Ottawa, 2009. 94 p. 
BANCO NACIONAL DE DESENVOLVIMENTO ECONÔMICO E SOCIAL. Panorama de mercado: painéis de madeira. 32. ed. Rio de Janeiro, 20I0. Disponível em: <http://www.bndes.gov.br/SiteBNDES/export/sites/ default/bndes_pt/Galerias/Arquivos/conhecimento/bnset/ set32।02.pdf >. Acesso em: I out. 2013.

BARROS FILHO, R. M.; MENDES, L. M.; NOVACK, K. M.; APRELINI, L. O.; BOTARO, V. R. Hybrid chipboard panels based on sugarcane bagasse, urea formaldehyde and melamine formaldehyde resins. Industrial Crops and Products, Amsterdam, v. 33, p. 369-373, $201 \mathrm{I}$.

BAUER, C. H. Diesel, burned in building machine: GLO 2004-2004. Switzerland: Ecoinvent Centre, 2007. Ecoinvent database.

BENETTO, E.; BECKER, M.; WELFRING, J. Life cycle assessment of Oriented Strand Boards (OSB): from process innovation to ecodesign. Environmental Science \& Technology, lowa City, v. 43, n. 15, p. 60036009, 2009.

BRASIL. Ministério de Minas e Energia. Balanço energético nacional 20I I: ano base 2010. Rio de Janeiro: EPE, 20II. $265 \mathrm{p}$.

GONZÁLEZ-GARCÍA, S.; FEIJOO, G.; WIDSTEN, P.; KANDELBAUER, A.; ZIKULNIG-RUSCH, E.; MOREIRA, M. T. Environmental performance assessment of hardboard manufacture. The International Journal of Life Cycle Assessment, Heidelberg, v. 14, n. 5, p. 456466, 2009.

LÖFGREN, B.; TILLMAN, A.; RINDE, B. Manufacturing actor's LCA. Journal of Cleaner Production, Amsterdam, v. 19, n. 17/18, p. 2025-2033, Nov./Dec. 201 I.

RIBEIRO, F. M.; SILVA, G. A. Life-cycle inventory for hydroelectric generation: a Brazilian case study. Journal of Cleaner Production, Amsterdam, v. I8, n. I, p. 44-54, Jan. 2010.
RIVELA, B.; HOSPIDO, A.; MOREIRA, M. T.; FEIJOO, G. Life cycle inventory of particleboard: a case study in the wood sector. The International Journal of Life Cycle Assessment, Heidelberg, v. II, n. 2, p. I06-I I3, 2006.

RIVELA, B.; MOREIRA, M. T.; FEIJOO, G. Life cycle inventory of medium density fibreboard. The International Journal of Life Cycle Assessment, Heidelberg, v. 12, n. 3, p. 143 I50, 2007.

SCHWAIGER, H.; ZIMMER, B. Energy, carbon and other material flows in the life cycle assessment of forestry and forest products. Helsinki: European Forest Institute, 200I.

SILVA, D. A. L.; LAHR, F. A. R.; GARCIA, R. P.; FREIRE, F. M. C.; OMETTO, A. R. Life cycle assessment of medium density particleboard (MDP) produced in Brazil. The International Journal of Life Cycle Assessment, Heidelberg, v. 18, p. |404-|4| I, 2013.

SILVA, D. A. L.; VARANDA, L. D.; CHRISTOFORO, A. L.; LAHR, F. A. R. Addition of impregnated paper residue to produce MDP wood panel: example of solidwaste. International Journal of Materials Engineering, Rosemead, v. 2, p. 75-79, 2012.

UNITED NATIONS ENVIRONMENTAL PROGRAMME. Global guidance principles for life cycle assessment databases: a basis for greener processes and products. Paris: UNEP-SETAC Life Cycle Initiative, 20I I. I56 p.

UNITED STATES ENVIRONMENTAL PROTECTION AGENCY. Wood waste combustion in boilers. Washington, 2003. 20 p.

WASTE \& RESOURCES ACTION PROGRAMME. Life cycle assessment of closed loop MDF recycling: microrelease trial. Glunz, 2009. 49 p.

WILSON, J. B. Life-cycle inventory of medium density fiberboard in terms of resources, emissions, energy and carbon. Wood and Fiber Science, Madison, v. 42, p. I07124, Mar. 2010. 